\title{
Erratum to: Disappointment and adherence among parents of newborns allocated to the control group: a qualitative study of a randomized clinical trial
}

Sandra Meinich Petersen ${ }^{1 *}$, Vibeke Zoffmann ${ }^{2,3}$, Jesper Kjærgaard ${ }^{1}$, Lone Graff Stensballe ${ }^{4}$ and Gorm Greisen ${ }^{1}$

\section{Erratum}

After publication of this work [1], it has come to our attention that Lone Graff Stensballe's surname was displayed incorrectly. The full list of authors has now been updated. We are publishing this erratum to update the author list, which is as follows:

Sandra Meinich Petersen, Vibeke Zoffmann, Jesper Kjærgaard, Lone Graff Stensballe and Gorm Greisen.

\begin{abstract}
Author details
'Department of Neonatology, the Danish National Hospital - "Rigshospitalet", Copenhagen, Denmark. ${ }^{2}$ Steno Diabetes Center, Gentofte, Denmark. ${ }^{3}$ NKLMS, Oslo Universitetssykehus, Oslo, Norway. ${ }^{4}$ The Child and Adolescent Clinic, the Danish National Hospital - "Rigshospitalet", Copenhagen, Denmark.
\end{abstract}

Received: 9 February 2015 Accepted: 20 February 2015

Published online: 14 March 2015

\section{Reference}

1. Petersen SM, Zoffmann V, Kjærgaard J, Steensballe LG, Greisen G.

Disappointment and adherence among parents of newborns allocated to the control group: a qualitative study of a randomized clinical trial. Trials. 2014;15:126

* Correspondence: sandrameinich@gmail.com

'Department of Neonatology, the Danish National Hospital - "Rigshospitalet", Copenhagen, Denmark

Submit your next manuscript to BioMed Central and take full advantage of:

- Convenient online submission

- Thorough peer review

- No space constraints or color figure charges

- Immediate publication on acceptance

- Inclusion in PubMed, CAS, Scopus and Google Scholar

- Research which is freely available for redistribution

Submit your manuscript at www.biomedcentral.com/submit
() Biomed Central 